\title{
www.czasopisma.pan.pl \\ Influence of Heat Treatment on Content of the Carbide Phases in the Microstructure of High-Speed Steel
}

\author{
J. Jaworski *, R. Kluz, T. Trzepieciński \\ Rzeszow University of Technology, al. Powstańców Warszawy 8, 35-959 Rzeszów, Poland \\ *Corresponding author. E-mail address: jjktmiop@prz.edu.pl
}

Received 14.03.2017; accepted in revised form 29.06.2017

\begin{abstract}
This article presents the results of investigations of the effect of heat treatment temperature on the content of the carbide phase of HS3-1-2 and HS6-5-2 low-alloy high-speed steel. Analysis of the phase composition of carbides is carried out using the diffraction method. It is determined that with increasing austenitising temperature, the intensification of dissolution of $\mathrm{M}_{6} \mathrm{C}$ carbide increases. As a result, an increase in the grain size of the austenite and the amount of retained austenite causes a significant reduction in the hardness of hardened steel HS3-1-2 to be observed. The results of diffraction investigations showed that $\mathrm{M}_{7} \mathrm{C}_{3}$ carbides containing mainly Cr and Fe carbides and $\mathrm{M}_{6} \mathrm{C}$ carbides containing mainly $\mathrm{Mo}$ and $\mathrm{W}$ carbides are dissolved during austenitisation. During austenitisation of HS3-1-2 steel, the silicon is transferred from the matrix to carbides, thus replacing carbide-forming elements. An increase in a degree of tempering leads to intensification of carbide separation and this process reduce the grindability of tested steels.
\end{abstract}

Keywords: Heat treatment, Metallography, Carbide phase, High-speed steel, Microstructure

\section{Introduction}

High-speed steel (HSS) is complex iron-based alloy containing carbon, tungsten, molybdenum, vanadium, chromium and substantial amounts of cobalt [1]. To ensure applicable quality requirements during production of tools made of HSSs, it is very important that their cutting ability is not lower than comparable tools made of classic high-speed steels [2].

In the case of cutting tools, the maximum efficiency is determined mainly by hardness, strength and temperability of the tool material $[3,4]$. These properties of the tool material can be adjusted within a relatively wide range by the parameters of the heat treatment [5]. Optimum heat treatment parameters ensure that the highest hardness, strength and temperability are achieved at the same time [6]. Determination of the optimum austenitising temperature requires special attention because it regulates a number of important processes. On the one hand, with an increase in austenitising temperature higher dissolution of secondary carbides is observed, which increases temperability and strength. On the other hand when steel material is overheated to too high a temperature an excessive growth of grains is observed, which increases the amount of retained austenite. However, in the case of smaller carbon content in steel, ferrite can be formed or even part melting of the grain boundaries can occur. HSSs should be used in a state of high hardness, which involves the determination of the optimum temperatures of austenitising and tempering [2, 79]. Austenitising temperature of a tool steel set in the process of tool manufacture should produce a grain size determined by the Snyder-Graff of no less than 10, a bending strength of 2500-3000 $\mathrm{MPa}$ and a hardness of about 63 HRC.

Microstructural changes occurring in tool during grinding process depend mainly on the chemical composition of material, 
thermal treatment and grinding parameters. The investigations of the effect of heat treatment on the coefficient of grinding [1] showed that this coefficient depends more on the fold of tempering than on the austenitization temperature. Both of these parameters determine the number and size of carbide phases leading to a decrease in the coefficient of grinding. The aim of this research is phase analysis and determination of the content of elements in carbide phases in HS3-1-2 and HS6-5-2 steels subjected to different heat treatment conditions.

\section{Methods}

Analysis of the phase composition of carbides is carried out using the diffraction method. The research material was prepared in the form of isolates containing carbon bound into carbides and unbounded carbon in solid solution. These isolates were obtained by electrolytic dissolution of samples. Conditions of electrolysis and the chemical composition of the electrolyte are shown in Table 1.

The isolate was removed from the sample by ultrasonic method. Then the isolate was washed in a centrifuge and dried in an evaporating dish at $105^{\circ} \mathrm{C}$. Isolates were tested using the diffractometer. Copper and chromium lamps with a nickel filter were used. The wavelength of $\mathrm{CuK} \alpha$ radiation was $\lambda=0.229092$ $\mathrm{nm}$. An analysis of the phase composition was performed for both grades of steel after annealing, hardening and tempering at $620^{\circ} \mathrm{C}$ for 4 hours. The HS3-1-2 steel was hardened at temperatures of $1080^{\circ} \mathrm{C}, 1120^{\circ} \mathrm{C}$ and $1150^{\circ} \mathrm{C}$. The HS6-5-2 steel was hardened at a temperature of $1200^{\circ} \mathrm{C}$ and tempered at $550^{\circ} \mathrm{C}$ for 2 hours. The grain size was determined using Snyder-Graff (S-G) intercept method.

Determination of element contents in carbides was carried out via atomic absorption spectrometry (AAS), using a Perkin-Elmer model 503 atomic absorption spectrometer. The AAS method was used to determine the content of Fe, Cr, Mn, W, V, Mn and Si in the HS3-1-2 steel after the heat treatment processes. Isolates were dissolved in a solution of $\mathrm{HNO}_{3}$ concentrated by $4 \%$ solution of $\mathrm{NaF}$ in the proportion 1:1, with later addition of hydrofluoric acid. The resulting percentages of elements in the isolate $x$ were converted to percentages in carbides $y$ according to the relationship:

$a=\frac{x}{b} \cdot 100 \%$

$y=\frac{x}{B} \cdot 100 \%$ where :

$x$ - the content of the element in isolate determined by AAS method $(\%)$,

$y$ - the content of the element in carbides (\%),

$a$ - the content of the element in isolate (\%),

$b$ - isolate mass $(\mathrm{g})$,

$\mathrm{B}-$ mass of the specimen part dissoluted electrolytically ( $\mathrm{g}$ ).

\section{Results and discussion}

The results of the phase analysis for tested steels according to the austenitising temperature are shown in Table 2. A significant dissolution of the $\mathrm{M}_{7} \mathrm{C}_{3}$ and $\mathrm{M}_{6} \mathrm{C}$ carbides in HS3-1-2 at austenitising temperatures of $1120^{\circ} \mathrm{C}$ and $1150^{\circ} \mathrm{C}$ was observed, while no visible dissolution of the $\mathrm{MC}$ carbide at these temperatures was observed. Simultaneously, no $\mathrm{M}_{2} \mathrm{C}$ primary carbide, besides MC carbide in HS3-1-2 steel, was revealed. The $\mathrm{M}_{2} \mathrm{C}$ carbide did not occur in the microstructure in spite of the high carbon content in the HS3-1-2 steel, as this steel was additionally enriched by nitrogen. The phase analysis of HS6-5-2 steel revealed the dissolution of $\mathrm{M}_{23} \mathrm{C}_{6}$ type carbide at temperatures below $1210^{\circ} \mathrm{C}$. The microstructure of tested steels is composed of alloying ferrite and carbides.

The composition of the carbide phase is similar after all heat treatment operations. Diffraction studies did not reveal significant differences between the carbide phases in hardened steel and carbide phases after tempering. This is due to two factors:

- the intensity of the deflected diffracted X-ray line for the family of planes affects not only the volume fraction of the specific phase in the solution but also has an influence on factors such as the chemical composition of the phases and the phase texturing.

- $\quad$ carbide precipitates are very small, so they can be revealed by the diffraction pattern.

It is known that when heating the steel for tempering, first $\mathrm{M}_{7} \mathrm{C}_{3}$ carbides are dissolved and $\mathrm{M}_{6} \mathrm{C}$ and $\mathrm{MC}$ carbides inhibit the grain growth. $\mathrm{M}_{6} \mathrm{C}$ carbide dissolution begins to intensify with an increase in austenitising temperature and as a result the size of austenite grains (Fig. 1) and the amount of residual austenite (Table 3) increase, causing a significant reduction in the hardness of HS3-1-2 hardened steel.

The grains in the samples hardened at a temperature of $1120^{\circ} \mathrm{C}$ are greater than in the samples hardened at $1160^{\circ} \mathrm{C}$ (Fig. $3)$, despite having the same annealing time and batch size.

Table 1.

Electrolysis conditions and chemical composition of the electrolyte

\begin{tabular}{llll}
\hline Steel grade & Composition of the electrolyte & Current density, $\mathrm{A} / \mathrm{cm}^{2}$ & Time of electrolysis, min. \\
\hline HS3-1-2 & $\begin{array}{l}150 \mathrm{~g} \mathrm{KCl}+10 \mathrm{~g} \text { of citric acid }+15 \mathrm{ml} \\
\text { of } \mathrm{HCL} \mathrm{per} 1 \mathrm{dm}^{3} \text { of } \mathrm{H}_{2} \mathrm{O}\end{array}$ & 30 & 8 \\
\hline $\mathrm{HS} 6-5-2$ & $\begin{array}{l}1150 \mathrm{ml} \mathrm{CH} \mathrm{HH}_{3} \mathrm{OH} 15 \mathrm{~g} \text { of citric acid } \\
+50 \mathrm{ml} \text { of HCL per } 1 \mathrm{dm}^{3} \text { of } \mathrm{H}_{2} \mathrm{O}\end{array}$ & 3 & 90 \\
\hline
\end{tabular}


Table 2.

Results of phase analysis

Steel grade

\begin{tabular}{|c|c|c|}
\hline Heat treatment & Occuring carbides & Comments \\
\hline soft annealing & $\begin{array}{l}\mathrm{M}_{6} \mathrm{C}, \mathrm{M}_{7} \mathrm{C}_{3} \\
\mathrm{MC}, \mathrm{M}_{23} \mathrm{C}_{6}\end{array}$ & $\mathrm{M}_{7} \mathrm{C}_{3}-$ trace amount \\
\hline austenitization at $1210^{\circ} \mathrm{C}$ & $\mathrm{M}_{6} \mathrm{C}, \mathrm{MC}$ & $\begin{array}{l}\text { isotale contain very small particles of } \\
\text { martensite }\end{array}$ \\
\hline $\begin{array}{l}\text { austenitization at } 1210^{\circ} \mathrm{C}+ \\
\text { tempering at } 550^{\circ} \mathrm{C} \text { for } 2 \text { hours }\end{array}$ & $\mathrm{M}_{6} \mathrm{C}, \mathrm{MC}$ & lack of martensite \\
\hline $\begin{array}{l}\text { austenitization at } 1210^{\circ} \mathrm{C}+ \\
\text { tempering at } 550^{\circ} \mathrm{C}(2 \text { hours })+ \\
\text { tempering at } 620^{\circ} \mathrm{C}(4 \text { hours })\end{array}$ & $\mathrm{M}_{6} \mathrm{C}, \mathrm{MC}$ & \\
\hline soft annealing & $\mathrm{M}_{6} \mathrm{C}, \mathrm{MC}, \mathrm{M}_{7} \mathrm{C}_{3}$ & \\
\hline austenitization at $1080^{\circ} \mathrm{C}$ & $\mathrm{M}_{6} \mathrm{C}, \mathrm{MC}, \mathrm{M}_{7} \mathrm{C}_{3}$ & \\
\hline austenitization at $1120^{\circ} \mathrm{C}$ & $\mathrm{M}_{6} \mathrm{C}, \mathrm{MC}, \mathrm{M}_{7} \mathrm{C}_{3}$ & $\begin{array}{l}\text { significant reduction of content of } \\
\text { carbides } \mathrm{M}_{6} \mathrm{C} \text { and } \mathrm{M}_{7} \mathrm{C}_{3} \text { compared to } \\
\text { austenitization at } 1180^{\circ} \mathrm{C} \text { is observed }\end{array}$ \\
\hline austenitization at $1150^{\circ} \mathrm{C}$ & $\mathrm{M}_{6} \mathrm{C}, \mathrm{MC}, \mathrm{M}_{7} \mathrm{C}_{3}$ & \\
\hline $\begin{array}{l}\text { austenitization at } 1120^{\circ} \mathrm{C}+ \\
\text { tempering at } 550^{\circ} \mathrm{C}(2 \text { hours })\end{array}$ & $\mathrm{M}_{6} \mathrm{C}, \mathrm{MC}, \mathrm{M}_{7} \mathrm{C}_{3}$ & $\begin{array}{l}\text { based on the data the variation of fraction } \\
\text { of individual phases in isolate cannot be } \\
\text { determined }\end{array}$ \\
\hline $\begin{array}{l}\text { austenitization at } 1120^{\circ} \mathrm{C}+ \\
\text { tempering at } 550^{\circ} \mathrm{C}(2 \text { hours })+ \\
\text { tempering at } 620^{\circ} \mathrm{C}(4 \text { hours })\end{array}$ & $\mathrm{M}_{6} \mathrm{C}, \mathrm{MC}, \mathrm{M}_{7} \mathrm{C}_{3}$ & \\
\hline
\end{tabular}

HS3-1-2

HS6-5-2

Table 3.

Physico-mechanical properties of HS3-1-2 steel

\begin{tabular}{|c|c|c|c|c|c|c|}
\hline \multirow{2}{*}{$\begin{array}{l}\text { Austenitizing } \\
\text { temperature, } \\
{ }^{\circ} \mathrm{C} \\
\end{array}$} & \multirow{2}{*}{$\begin{array}{l}\text { Hardness after } \\
\text { hardening } \\
\text { HRC }\end{array}$} & \multirow[t]{2}{*}{ Grain size } & \multicolumn{2}{|c|}{ After twice tempering $\left(550^{\circ} \mathrm{C}, 2\right.$ hours $)$} & \multicolumn{2}{|c|}{ After triply tempering $\left(550^{\circ} \mathrm{C}, 1\right.$ hour $)$} \\
\hline & & & Hardness HRC & Retained austenite, $\%$ & Hardness HRC & Retained austenite, $\%$ \\
\hline 1080 & 61 & 13 & 61 & 15 & 62 & - \\
\hline 1100 & 61 & $12-13$ & 62 & 16.5 & 62 & - \\
\hline 1120 & 60 & $11-12$ & 62 & 18 & 62.5 & 2 \\
\hline 1140 & 59 & $10-11$ & 63 & 19.5 & 63 & 4 \\
\hline 1160 & 57 & 8 & 60 & 21 & 62 & 14.5 \\
\hline 1180 & 53 & 7 & 55 & 30 & 61.5 & 21 \\
\hline
\end{tabular}

Table 4.

The chemical composition of carbide isolate in HS3-1-2

\begin{tabular}{|c|c|c|c|c|c|c|c|}
\hline \multirow{2}{*}{ Heat treatment of isolate } & \multicolumn{7}{|c|}{ Chemical composition in isolate, $\%$ wt. } \\
\hline & $\mathrm{Fe}$ & $\mathrm{Mn}$ & $\mathrm{Cr}$ & $\mathrm{W}$ & Mo & $\mathrm{V}$ & $\mathrm{Si}$ \\
\hline soft annealing & 33.79 & 0.65 & 20.54 & 13.25 & 5.28 & 8.12 & 0.83 \\
\hline austenitization at $1080^{\circ} \mathrm{C}$ & 21.33 & 0.31 & 13.21 & 11.75 & 4.08 & 9.75 & 5.84 \\
\hline austenitization at $1120^{\circ} \mathrm{C}$ & 11.16 & 0.12 & 6.34 & 9.84 & 3.75 & 9.84 & 9.26 \\
\hline austenitization at $1150^{\circ} \mathrm{C}$ & 5.13 & 0.05 & 3.68 & 8.43 & 2.97 & 9.74 & 8.65 \\
\hline $\begin{array}{l}\text { austenitization at } 1120^{\circ} \mathrm{C}+\text { tempering at } \\
550^{\circ} \mathrm{C} \text { for } 2 \text { hours }\end{array}$ & 15.24 & 0.18 & 9.36 & 13.15 & 4.27 & 9.40 & 5.86 \\
\hline $\begin{array}{l}\text { austenitization at } 1120^{\circ} \mathrm{C}+\text { tempering at } \\
550^{\circ} \mathrm{C} \text { for } 2 \text { hours }+ \text { tempering at } 620^{\circ} \mathrm{C} \\
\text { for } 4 \text { hours }\end{array}$ & 88.64 & 0.76 & 16.54 & 12.14 & 4.57 & 9.27 & 1.01 \\
\hline
\end{tabular}

After the third tempering the hardness of the steel significantly increases (Table 4) as a result of the evolution of a large number of carbides. As the sizes of these carbides are several times smaller than the primary carbides, their total area is significantly higher, which can result in a reduction of the grindability of the tested steels.

After the third tempering the hardness of the steel significantly increases (Table 3 ) as a result of the evolution of a large number of carbides. As the size of secondary carbides is 
several times smaller than the primary carbides, their total area is significantly higher, which can result in a reduction of the grindability of the tested steels. The results of the analysis of elements content in the carbide isolates in HS3-1-2 steel are shown in Table 4. During the austenitisation, dissolution of both the $\mathrm{M}_{7} \mathrm{C}_{3}$ carbides containing $\mathrm{Cr}$ and $\mathrm{Fe}$ and the $\mathrm{M}_{6} \mathrm{C}$ carbides containing mainly Mo and $\mathrm{W}$ is observed.

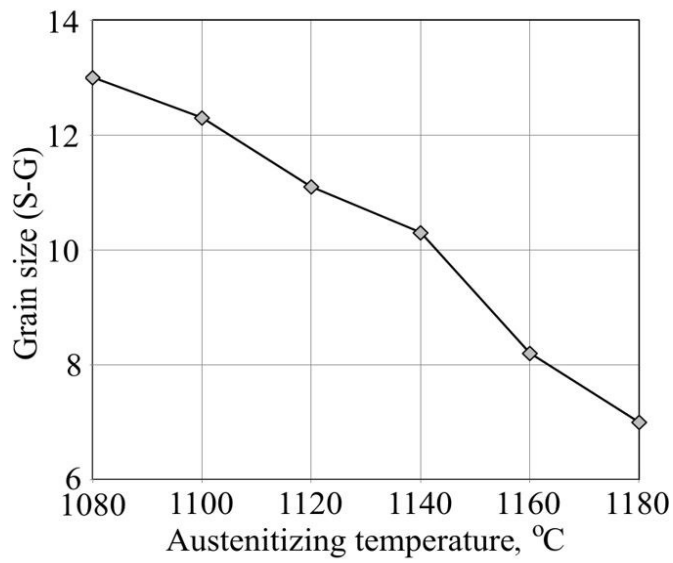

Fig. 1. The effect of austenitising temperature on the size of the austenite grain

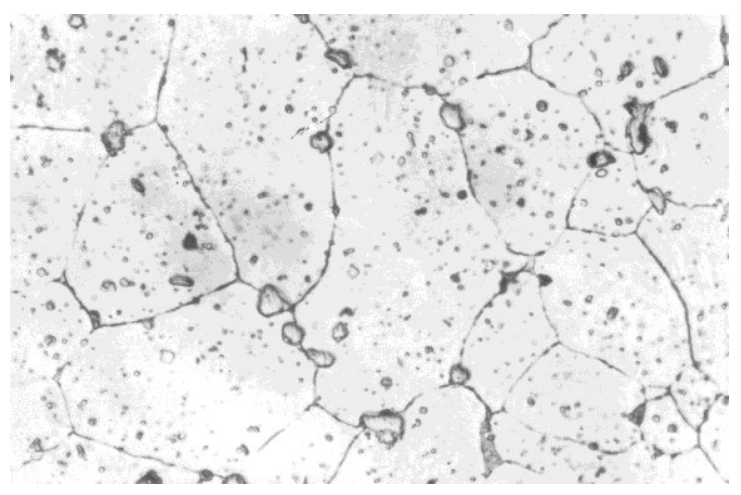

Fig. 2. Microstructure of the HS3-1-2 steel austenitized at $1160^{\circ} \mathrm{C}$; etching using reagent of $8 \% \mathrm{HNO}_{3}$; magnification $500 \times$

This is related to the transition of $\mathrm{Cr}, \mathrm{Fe}, \mathrm{Mo}$ and $\mathrm{W}$ carbides into the matrix. Vanadium is an element that transfers to matrix in a very small amount, which indicates no dissolution of the MC carbide. An increase in the content of elements in carbides after tempering is proof that the processes of separation or growth of carbides occurred. Of particular importance in this context is the change in silicon content in the steel during heat treatment processes (Table 4). The percentage of silicon increases with an increase in austenitising temperature. However, the percentage of silicon carbide decreases during the tempering. Thus, it should be concluded that during austenitisation the silicon is transferred into the carbides. Silicon is incorporated into the network of the $\mathrm{M}_{6} \mathrm{C}$ carbide, replacing the atoms of elements such as $\mathrm{Cr}, \mathrm{Fe}, \mathrm{Mn}, \mathrm{Mo}$, $\mathrm{V}$ and $\mathrm{W}$.

\section{Conclusions}

From the experimental results, the following conclusions can be drawn:

1. An increase in austenitising temperature intensifies the dissolution of $\mathrm{M}_{6} \mathrm{C}$ carbide causing an increase in the austenite grain size.

2. During austenitization the process of dissolution of $\mathrm{M}_{7} \mathrm{C}_{3}$ and $\mathrm{M}_{6} \mathrm{C}$ carbides occurs and, as a result of this process, elements such as $\mathrm{Cr}, \mathrm{Fe}, \mathrm{Mo}$, and $\mathrm{W}$ are separated from the matrix.

3. During austenitization silicon separates from the matrix to the carbides and simultaneously the carbide-forming elements in matrix are replaced.

4. An increase in a degree of tempering leads to intensification of carbide separation and this process can reduce the grindability of tested steels.

\section{References}

[1] Jaworski, J. (2009). The influence of grinding parameters of the surface layer of low-alloyed high-speed steel. Archives of Foundry Engineering. 9(1), 103-106.

[2] Jaworski, J. \& Trzepieciński, T. (2016). Research on durability of turning tools made of low-alloy high-speed steel. Kovove Mater. 54(1), 17-25. DOI: $10.4149 / \mathrm{km} 2016117$

[3] Pietrowski, S. \& Szymczak, T. (2010). Alfinated coating structure on HS6-5-2 (SW7M) high speed steel. Archives of Foundry Engineering. 10(4), 191-198.

[4] Bochnowski, W. (2009). The influence of arc plasma electric and laser treatment on the structure and properties of the high speed steel. Archives of Foundry Engineering. 9(3), 17-20.

[5] Lu, L., Hou, L.G., Zhang, J.X., Wang, H.B., Cui, H., Huang, J.F., Zhang, Y.A. \& Zhang, J.S. (2016). Improved the microstructures and properties of M3:2 high-speed steel by spray forming and niobium alloying. Mater. Charact. 117, 18. DOI: 10.1016/j.matchar.2016.04.010.

[6] Herranz, G., Romero, A., de Castro, V. \& Rodriguez, G.P. (2014). Processing of AISI M2 high speed steel reinforced with vanadium carbide by solar sintering. Mater. Design 54, 934-946. DOI: 10.1016/j.matdes.2013.09.027.

[7] Xu, L., Xing, J., Wei, S., Zhang, Y. \& Long, R. (2007). Optimization of heat treatment technique of high-vanadium high-speed steel based on back-propagation neural networks. Mater. Design. 28(5), 1452-1432. DOI: 10.1016/j.matdes.2006.03.022.

[8] Cao, H.T., Dong, X.P., Pan, Z., Wu, X.W., Huang, Q.W. \& Pei, Y.T. (2016). Surface alloying of high-vanadium highspeed steel on ductile iron using plasma transferred arc technique: Microstructure and wear properties. Mater. Design. 100, 223-234. DOI: 10.1016/j.matdes.2016.03.114.

[9] Sackl, S., Leitner, H., Clemens, H. \& Primig, S. (2016). On the evolution of secondary hardening carbides during continuous versus isothermal heat treatment of high speed steel HS 6-5-2. Mater. Charact. 120, 323-330. DOI: $10.1016 /$ j.matdes.2016 